\title{
FDI AND ECONOMIC GROWTH IN EU13 COUNTRIES: COINTEGRATION AND CAUSALITY TESTS
}

\section{- Vlatka Bilas}

\begin{abstract}
Foreign direct investments are seen as a prerequisite for gaining and maintaining competitiveness. The research objective of this study is to examine the relationship between foreign direct investment (FDI) and economic growth in "new" European Union member countries using various unit root, cointegration, as well as causality tests. The paper employs annual data for FDI and gross domestic product (GDP) from 2002 to 2018 for the 13 most recent members of European Union (EU13): Bulgaria, Croatia, Cyprus, the Czech Republic, Estonia, Hungary, Latvia, Lithuania, Malta, Poland, Romania, Slovakia and Slovenia. An estimated panel ARDL (PMG) model found evidence that there is a long-run equilibrium between the LogGDP, LogFDI and LogFDIP series, with the rate of adjustment back to equilibrium between $3.27 \%$ and $20.67 \%$. In the case of the LogFDI series, long-run coefficients are highly statistically significant in all four models, varying between 0.0828 and 0.3019 . These coefficients indicate that a $1 \%$ increase in LogFDI increases LogGDP between $0.0828 \%$ and $0.3019 \%$. Results of a Dumitrescu-Hurlin panel causality test indicated that a relationship between the GDP growth rate and FDI growth rate is only indirect. Finally, only weak evidence was shown that FDI had a statistically significant impact on GDP in the EU13 countries over the period 2002-2018. This report of findings contributes to the literature concerning FDI and economic growth, namely regarding the current understanding of the relationship between these two factors.
\end{abstract}

Keywords: FDI, competitiveness, economic growth, unit root tests, cointegration test (ARDL), EU13, Granger causality

JEL Classification: F21, F43, F15

Received: December, 2019

1st Revision: April, 2020

Accepted: June, 2020

\section{INTRODUCTION}

Four types of FDI can be determined depending on the motive for investment: market seeking, resource seeking, efficiency seeking and strategic asset seeking (Meyer, 2015).

Theories on FDI and economic growth emphasize the relationship between these two variables, with FDI found to be important for economic growth especially in developing countries 
(Sothan, 2017). Markusen \& Venables (1997) determined that FDI leads to the development of local industry in the host country. Stanisic (2008) claims that FDI, besides the effect on economic growth, produces one more important effect on the host economies - export performance. However, empirical evidence on the issues involved has been mixed.

The aim of this paper is to examine the relationship between GDP and economic growth using the sample of the 13 "new" European Union countries (EU13), all of which began EU membership in 2004.

The paper is organized in five sections. The Theoretical background gives an overview of previous international researches. The part Methodology introduces research data and methodology used for their processing. The section Results and discussion describes the empirical analysis and compares the results from the international point of view. The final section presents conclusions.

\section{THEORETICAL BACKGROUND}

Iacovoiu (2018) analysed a sample of 177 world countries in 2017. He found, that the relationship between the level of economic development and foreign direct investment flows is positive but weak. One of the results indicated that GDP per capita does not fully explain differences in flow of FDI. Iamsiraroj \& Ulubaşoğlu (2015) found that FDI positively influences economic growth. They used a sample of 140 countries during years 1970-2009.

Ausloos et al. (2019) analysed the relationship between GDP and FDI with regard to time lags using a sample of 43 countries grouped according to the Inequality-Adjusted Human Development Index over the period 1970-2015. They found that there is a time lag dependence effect in FDI-GDP correlations.

Lasbrey et al. (2018) examined literature related to the relationship between economic growth and FDI over the period 1998-2018 and found mixed results, although a significantly positive impact of FDI on economic growth prevailed. Interestingly, among the important determinants for FDI the researchers identified such factors as location market size, human capital, financial development, economic freedom, availability of internet, etc.

Cicak \& Soric (2015) found that FDI Granger has caused GDP growth in most of the ten European transition countries that were examined. For the period 2005-2016, Su et al. (2018) found a significant relationship between FDI, the corruption index and a labour force with advanced education, but only in the long term in the Visegrad group countries (Poland, Hungary, Czech Republic and Slovakia) after the EU enlargement. Stanisic (2008) did not find a positive correlation between FDI and economic growth using a sample of seven countries of Southeast Europe over the period 1997-2006. One of the reasons for these results was seen by Stanisic (2008) in structural reforms of these countries. Namely, a production decrease and employment in inefficient domestic firms can neutralize or deviate the positive effect of FDI on economic growth. Kurecic et al. (2015) examined the influence of GDP per capita on FDI in the transitional economies of countries from Central and Eastern Europe area, both EU members and non-EU members (Albania, Belarus, Bosnia-Herzegovina, Bulgaria, Croatia, the Czech Republic, Estonia, 
Hungary, Kosovo, Latvia, Lithuania, Macedonia, Moldova, Montenegro, Poland, Romania, Serbia, Slovakia, Slovenia, Ukraine) over the period 1994-2013. The researchers found a relation between FDI and GDP per capita, although it would be difficult to prove causality. Popescu (2014) points out the importance of absorptive capacity in establishing the impact of FDI on productivity growth in these countries.

Vojtovic et al. (2019) examined linkages between FDI and GDP in 11 Central and Eastern European (CEE) countries over the period 1997-2004. The examiners determined that the relative size of economic growth indicators affects FDI, and that FDI has an impact on economic growth which is strengthened by financial market development.

Moudatsou (2003) studied the growth effects of FDI in the EU countries over the period 19801996. The results of his research show the positive effect of FDI on the growth of EU economies. The effect is positive directly and indirectly through trade strengthening. Nevertheless, if each country is analysed separately, FDI current inflows do not affect the current growth of EU countries, while the past level of FDI does.

\section{RESEARCH OBJECTIVE, METHODOLOGY AND DATA}

The aim of the paper is to examine the relationship between FDI and economic growth in the most recent countries entering the EU using various cointegration as well as causality tests. Annual data for foreign direct investment (FDI) and gross domestic product (GDP) were used from 2002 to 2018 for 13 "new” members of European Union: Bulgaria, Croatia, Cyprus, the Czech Republic, Estonia, Hungary, Latvia, Lithuania, Malta, Poland, Romania, Slovakia and Slovenia. 17 observations for each series and each country are in a balanced panel. The data of World Bank were used. The variables are presented in Table 1. Descriptive statistics is given in Table 2 .

In order to achieve the research goal of the paper, there are employed all panel unit root tests available in EViews v. 10, as well as Stata v. 15 for certain tests, as it is explained in the following section.

Tab. 1 - The definitions of variables. Source: own research

\begin{tabular}{|l|l|}
\hline Variable & Description \\
\hline GDP & GDP, PPP (constant 2011 international \$) \\
\hline FDI & Foreign direct investment, net inflows (BoP, current US\$) \\
\hline FDIP & Foreign direct investment, net inflows (\% of GDP) \\
\hline rGDP & GDP growth rate $(\%)$ \\
\hline rFDI & FDI growth rate $(\%)$ \\
\hline rFDIP & FDIP growth rate $(\%)$ \\
\hline LogGDP & Natural logarithm of GDP series \\
\hline LogFDI & Natural logarithm of FDI series \\
\hline LogFDIP & Natural logarithm of FDIP series \\
\hline
\end{tabular}




\begin{tabular}{|l|l|}
\hline$\Delta \log G D P$ & The first difference of LogGDP series \\
\hline$\Delta \log F D I$ & The first difference of LogFDI series \\
\hline$\Delta \log F D I P$ & The first difference of LogFDIP series \\
\hline
\end{tabular}

Tab. 2 - The overview of descriptive statistics. Source: own research

\begin{tabular}{|l|l|l|l|l|l|}
\hline Variable & Obs & Mean & Std. Dev. & Min & Max \\
\hline gdp4 & 221 & $1.76 \mathrm{e}+11$ & $2.20 \mathrm{e}+11$ & $9.94 \mathrm{e}+09$ & $1.09 \mathrm{e}+12$ \\
\hline fdi & 221 & $4.94 \mathrm{e}+09$ & $1.16 \mathrm{e}+10$ & $-7.28 \mathrm{e}+10$ & $7.50 \mathrm{e}+10$ \\
\hline fdip & 221 & 14.1443 & 49.92809 & -46.76921 & 451.7155 \\
\hline rgdp4 & 221 & 3.235808 & 4.001129 & -14.81416 & 11.88939 \\
\hline rfdi & 221 & 52.25924 & 448.1399 & -1444.468 & 4712.521 \\
\hline rfdip & 221 & 39.3049 & 453.0398 & -1580.994 & 4754.027 \\
\hline $\operatorname{loggdp} 4$ & 221 & 25.26772 & 1.1364 & 23.02018 & 27.71899 \\
\hline $\operatorname{logfdi}$ & 221 & 18.78835 & 10.9574 & -25.01127 & 25.04093 \\
\hline $\operatorname{logfdip}$ & 221 & 1.639527 & 1.39773 & -3.866381 & 6.115264 \\
\hline dloggdp4 & 221 & .031065 & .0400541 & -.1603355 & .1123409 \\
\hline dlogfdi & 221 & -.3471995 & 13.76678 & -48.24342 & 47.8288 \\
\hline dlogfdip & 221 & -.0540663 & 1.657223 & -8.552417 & 9.088331 \\
\hline Note Orgin & & & &
\end{tabular}

Note: Original series: gdp4, fdi, fdip. Growth rates: rgdp4, rfdi, rfdip. Logarithm transformation: loggdp4, logfdi, logfdip. The first difference: dloggdp 4 , dlogfdi, dlogfdip

\section{RESULTS AND DISCUSSION}

\subsection{Unit root tests}

For testing Granger causality in panel datasets, the Stata user-written command xtgcause (Lopez \& Weber, 2017), which implements a procedure proposed by Dumitrescu \& Hurlin (2012), was used. For all the other estimations in this article, the econometric software EViews v. 10. was used. The results are presented the following table.

Performed tests (Levin et al., 2002, Breitung, 2000, 2002; Im et al., 2003; Dickey \& Fuller, 1979; 1981) are the first generation of panel unit root tests and do not take into account possible cross-section dependences. These tests are the first generation of panel unit root tests. However, these tests are not taking into account possible cross-section dependences. Therefore, the second-generation panel unit root tests were developed. 
Tab. 3 - Presentation of first generation panel unit root tests. Source: own research

\begin{tabular}{|c|c|c|c|c|c|c|c|c|}
\hline & \multicolumn{3}{|c|}{$\begin{array}{l}\text { Null hypothesis: } \\
\text { Unit root - common root }\end{array}$} & \multicolumn{3}{|c|}{$\begin{array}{l}\text { Null hypothesis: } \\
\text { Unit root - individual root }\end{array}$} & \multicolumn{2}{|c|}{$\begin{array}{l}\text { Null hypothesis: } \\
\text { Stationarity }\end{array}$} \\
\hline & Variables & $\begin{array}{l}\text { Levin, } \\
\text { Lin \& } \\
\text { Chu t- } \\
\text { statistic }\end{array}$ & $\begin{array}{l}\text { Brei- } \\
\text { tung t- } \\
\text { statistic }\end{array}$ & $\begin{array}{l}\text { Im, } \\
\text { Pasaran } \\
\& \text { Shin } \\
\text { W-sta- } \\
\text { tistic }\end{array}$ & $\begin{array}{l}\text { ADF } \\
\text { Fisher } \\
\text { Chi- } \\
\text { square }\end{array}$ & $\begin{array}{l}\text { PP } \\
\text { Fisher } \\
\text { Chi- } \\
\text { square }\end{array}$ & $\begin{array}{l}\text { Hadri } \\
\text { Z-sta- } \\
\text { tistic }\end{array}$ & $\begin{array}{l}\text { Hetero- } \\
\text { scedastic } \\
\text { consistent } \\
\text { Z-statistic }\end{array}$ \\
\hline \multirow{9}{*}{ 己 } & GDP & $\begin{array}{l}0.18 \\
(.57)\end{array}$ & $\begin{array}{l}-1.90 \\
(.03)\end{array}$ & $\begin{array}{l}0.57 \\
(.71)\end{array}$ & $\begin{array}{l}21.63 \\
(.71)\end{array}$ & $\begin{array}{l}9.64 \\
(.99)\end{array}$ & $\begin{array}{l}2.58 \\
(<.01)\end{array}$ & $\begin{array}{l}3.52 \\
(<.01)\end{array}$ \\
\hline & FDI & $\begin{array}{l}-5.44 \\
(<.01)\end{array}$ & $\begin{array}{l}-4.91 \\
(<.01)\end{array}$ & $\begin{array}{l}-4.15 \\
(<.01)\end{array}$ & $\begin{array}{l}59.55 \\
(<.01)\end{array}$ & $\begin{array}{l}56.69 \\
(<.01)\end{array}$ & $\begin{array}{l}5.29 \\
(<.01)\end{array}$ & $\begin{array}{l}4.40 \\
(<.01)\end{array}$ \\
\hline & FDIP & $\begin{array}{l}-6.07 \\
(<.01)\end{array}$ & $\begin{array}{l}-6.07 \\
(<.01)\end{array}$ & $\begin{array}{l}-5.28 \\
(<.01)\end{array}$ & $\begin{array}{l}70.90 \\
(<.01)\end{array}$ & $\begin{array}{l}63.10 \\
(<.01)\end{array}$ & $\begin{array}{l}2.25 \\
(.01)\end{array}$ & $\begin{array}{l}5.57 \\
(<.01)\end{array}$ \\
\hline & rGDP & $\begin{array}{l}-6.06 \\
(<.01)\end{array}$ & $\begin{array}{l}-6.18 \\
(<.01)\end{array}$ & $\begin{array}{l}-2.18 \\
(.01)\end{array}$ & $\begin{array}{l}39.45 \\
(.04)\end{array}$ & $\begin{array}{l}29.49 \\
(.29)\end{array}$ & $\begin{array}{l}3.91 \\
(<.01)\end{array}$ & $\begin{array}{l}4.43 \\
(<.01)\end{array}$ \\
\hline & $\mathrm{rFDI}$ & $\begin{array}{l}-10.74 \\
(<.01)\end{array}$ & $\begin{array}{l}-9.30 \\
(<.01)\end{array}$ & $\begin{array}{l}-8.84 \\
(<.01)\end{array}$ & $\begin{array}{l}109.59 \\
(<.01)\end{array}$ & $\begin{array}{l}141.87 \\
(<.01)\end{array}$ & $\begin{array}{l}3.86 \\
(<.01)\end{array}$ & $\begin{array}{l}11.17 \\
(<.01)\end{array}$ \\
\hline & rFDIP & $\begin{array}{l}-10.96 \\
(<.01)\end{array}$ & $\begin{array}{l}-9.48 \\
(<.01)\end{array}$ & $\begin{array}{l}-8.99 \\
(<.01)\end{array}$ & $\begin{array}{l}111.39 \\
(<.01)\end{array}$ & $\begin{array}{l}148.86 \\
(<.01)\end{array}$ & $\begin{array}{l}3.90 \\
(<.01)\end{array}$ & $\begin{array}{l}10.51 \\
(<.01)\end{array}$ \\
\hline & LogGDP & $\begin{array}{l}-1.01 \\
(.16)\end{array}$ & $\begin{array}{l}-1.70 \\
(.04) \\
\end{array}$ & $\begin{array}{l}0.44 \\
(.67)\end{array}$ & $\begin{array}{l}20.50 \\
(.77)\end{array}$ & $\begin{array}{l}10.93 \\
(.99)\end{array}$ & $\begin{array}{l}4.11 \\
(<.01)\end{array}$ & $\begin{array}{l}4.47 \\
(<.01)\end{array}$ \\
\hline & LogFDI & $\begin{array}{l}-8.80 \\
(<.01)\end{array}$ & $\begin{array}{l}-6.40 \\
(<.01)\end{array}$ & $\begin{array}{l}-6.61 \\
(<.01)\end{array}$ & $\begin{array}{l}85.03 \\
(<.01)\end{array}$ & $\begin{array}{l}98.63 \\
(<.01)\end{array}$ & $\begin{array}{l}3.97 \\
(<.01)\end{array}$ & $\begin{array}{l}6.11 \\
(<.01)\end{array}$ \\
\hline & LogFDIP & $\begin{array}{l}-7.04 \\
(<.01)\end{array}$ & $\begin{array}{l}-6.65 \\
(<.01)\end{array}$ & $\begin{array}{l}-5.34 \\
(<.01)\end{array}$ & $\begin{array}{l}71.89 \\
(<.01)\end{array}$ & $\begin{array}{l}70.52 \\
(<.01)\end{array}$ & $\begin{array}{l}4.58 \\
(<.01)\end{array}$ & $\begin{array}{l}4.30 \\
(<.01)\end{array}$ \\
\hline \multirow{7}{*}{ 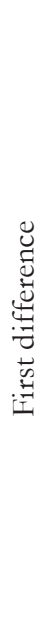 } & $\Delta \mathrm{GDP}$ & $\begin{array}{l}-6.33 \\
(<.01)\end{array}$ & $\begin{array}{l}-6.36 \\
(<.01)\end{array}$ & $\begin{array}{l}-2.30 \\
(.01)\end{array}$ & $\begin{array}{l}40.62 \\
(.03)\end{array}$ & $\begin{array}{l}29.97 \\
(.27)\end{array}$ & $\begin{array}{l}4.86 \\
(<.01)\end{array}$ & $\begin{array}{l}4.88 \\
(<.01)\end{array}$ \\
\hline & $\Delta \mathrm{FDI}$ & $\begin{array}{l}-11.00 \\
(<.01)\end{array}$ & $\begin{array}{l}-8.50 \\
(<.01)\end{array}$ & $\begin{array}{l}-10.26 \\
(<.01) \\
\end{array}$ & $\begin{array}{l}129.17 \\
(<.01)\end{array}$ & $\begin{array}{l}184.31 \\
(<.01)\end{array}$ & $\begin{array}{l}15.89 \\
(<.01)\end{array}$ & $\begin{array}{l}15.89 \\
(<.01)\end{array}$ \\
\hline & $\Delta \mathrm{FDIP}$ & $\begin{array}{l}-11.24 \\
(<.01)\end{array}$ & $\begin{array}{l}-10.67 \\
(<.01)\end{array}$ & $\begin{array}{l}-11.02 \\
(<.01)\end{array}$ & $\begin{array}{l}138.88 \\
(<.01)\end{array}$ & $\begin{array}{l}201.57 \\
(<.01)\end{array}$ & $\begin{array}{l}2.27 \\
(.01)\end{array}$ & $\begin{array}{l}14.28 \\
(<.01)\end{array}$ \\
\hline & $\Delta \mathrm{rGDP}$ & $\begin{array}{l}-14.01 \\
(<.01)\end{array}$ & $\begin{array}{l}-11.98 \\
(<.01)\end{array}$ & $\begin{array}{l}-10.61 \\
(<.01)\end{array}$ & $\begin{array}{l}132.91 \\
(<.01)\end{array}$ & $\begin{array}{l}206.37 \\
(<.01)\end{array}$ & $\begin{array}{l}19.53 \\
(<.01)\end{array}$ & $\begin{array}{l}26.56 \\
(<.01)\end{array}$ \\
\hline & $\Delta \mathrm{rFDI}$ & $\begin{array}{l}-14.48 \\
(<.01)\end{array}$ & $\begin{array}{l}-3.21 \\
(<.01)\end{array}$ & $\begin{array}{l}-16.08 \\
(<.01)\end{array}$ & $\begin{array}{l}193.99 \\
(<.01)\end{array}$ & $\begin{array}{l}263.04 \\
(<.01)\end{array}$ & $\begin{array}{l}22.37 \\
(<.01)\end{array}$ & $\begin{array}{l}21.02 \\
(<.01)\end{array}$ \\
\hline & $\Delta \mathrm{rFDIP}$ & $\begin{array}{l}-13.33 \\
(<.01)\end{array}$ & $\begin{array}{l}-2.41 \\
(<.01)\end{array}$ & $\begin{array}{l}-15.15 \\
(<.01)\end{array}$ & $\begin{array}{l}183.30 \\
(<.01)\end{array}$ & $\begin{array}{l}258.30 \\
(<.01)\end{array}$ & $\begin{array}{l}18.14 \\
(<.01)\end{array}$ & $\begin{array}{l}21.64 \\
(<.01)\end{array}$ \\
\hline & $\Delta \log G D P$ & $\begin{array}{l}-6.19 \\
(<.01)\end{array}$ & $\begin{array}{l}-6.26 \\
(<.01) \\
\end{array}$ & $\begin{array}{l}-2.22 \\
(.01)\end{array}$ & $\begin{array}{l}39.62 \\
(.04)\end{array}$ & $\begin{array}{l}30.57 \\
(.24)\end{array}$ & $\begin{array}{l}3.91 \\
(<.01)\end{array}$ & $\begin{array}{l}4.46 \\
(<.01)\end{array}$ \\
\hline
\end{tabular}




\begin{tabular}{|l|l|l|l|l|l|l|l|l|}
\hline & DLogFDI & -14.92 & -8.67 & -13.31 & 162.74 & 228.40 & 22.35 & 27.10 \\
& $(<.01)$ & $(<.01)$ & $(<.01)$ & $(<.01)$ & $(<.01)$ & $\begin{array}{l}(<.01) \\
(<.01)\end{array}$ \\
\hline \multirow{2}{*}{$\Delta$ LogFDIP } & -10.01 & -7.97 & -11.10 & 137.55 & 220.62 & 11.07 & 19.12 \\
& & $(<.01)$ & $(<.01)$ & $(<.01)$ & $(<.01)$ & $(<.01)$ & $(<.01)$ & $(<.01)$ \\
\hline
\end{tabular}

Note: The following exogenous variables were included in the test equation: Individual effects, individual linear trends. Schwarz automatic selection of maximum lags criterion, Newey-West automatic bandwidth selection and Bartlett kernel were used.

The problem with all the first-generation panel unit root tests discussed in the previous section is that they assume cross-sectional independence. Contrary to this assumption, most of macroeconomic time series are cross-sectional dependent. For instance, it is reasonable to assume that Croatia's GDP does depend on Germany's GDP. Cross-sectional dependence in our data is represented in Table 4.

Tab. 4 - The statistic of the cross-sectional dependence test. Source: own research

\begin{tabular}{|l|l|l|l|l|}
\hline Variable & $\begin{array}{l}\text { Breusch-Pagan } \\
\text { LM }\end{array}$ & $\begin{array}{l}\text { Pesaran scaled } \\
\text { LM }\end{array}$ & $\begin{array}{l}\text { Bias-corrected } \\
\text { scaled LM }\end{array}$ & Pesaran CD \\
\hline GDP & $1025.88(<.01)$ & $75.89(<.01)$ & $75.48(<.01)$ & $31.83(<.01)$ \\
\hline FDI & $297.90(<.01)$ & $17.61(<.01)$ & $17.20(<.01)$ & $14.00(<.01)$ \\
\hline FDIP & $282.87(<.01)$ & $16.40(<.01)$ & $16.00(<.01)$ & $12.93(<.01)$ \\
\hline rGDP & $597.25(<.01)$ & $41.57(<.01)$ & $41.17(<.01)$ & $23.00(<.01)$ \\
\hline rFDI & $142.14(<.01)$ & $5.14(<.01)$ & $4.73(<.01)$ & $-0.31(.75)$ \\
\hline rFDIP & $160.64(<.01)$ & $6.62(<.01)$ & $6.21(<.01)$ & $-1.05(.29)$ \\
\hline LogGDP & $1041.12(<.01)$ & $77.11(<.01)$ & $76.71(<.01)$ & $32.10(<.01)$ \\
\hline LogFDI & $139.12(<.01)$ & $4.89(<.01)$ & $4.49(<.01)$ & $6.23(<.01)$ \\
\hline LogFDIP & $199.51(<.01)$ & $9.73(<.01)$ & $9.32(<.01)$ & $11.83(<.01)$ \\
\hline$\Delta$ GDP & $595.00(<.01)$ & $41.39(<.01)$ & $40.99(<.01)$ & $23.12(<.01)$ \\
\hline$\Delta$ FDI & $173.43(<.01)$ & $7.64(<.01)$ & $7.23(<.01)$ & $9.32(<.01)$ \\
\hline$\Delta$ FDIP & $128.75(<.01)$ & $4.06(<.01)$ & $3.66(<.01)$ & $6.20(<.01)$ \\
\hline$\Delta$ rGDP & $606.27(<.01)$ & $42.29(<.01)$ & $41.89(<.01)$ & $23.66(<.01)$ \\
\hline$\Delta$ rFDI & $219.09(<.01)$ & $11.30(<.01)$ & $10.89(<.01)$ & $-0.72(.47)$ \\
\hline$\Delta$ rFDIP & $239.10(<.01)$ & $12.90(<.01)$ & $12.49(<.01)$ & $-1.10(.27)$ \\
\hline$\Delta$ LogGDP & $607.22(<.01)$ & $42.37(<.01)$ & $41.97(<.01)$ & $23.24(<.01)$ \\
\hline$\Delta$ LogFDI & $157.71(<.01)$ & $6.38(<.01)$ & $5.98(<.01)$ & $3.86(<.01)$ \\
\hline$\Delta$ LogFDIP & $122.00(<.01)$ & $3.52(<.01)$ & $3.12(<.01)$ & $4.52(<.01)$ \\
\hline & & & & \\
\hline
\end{tabular}

Note: Cross-section means were removed during computation of correlations. Degree of freedom for all tests is 378. P-values for all test statistics are lower than $1 \%$. .

All the tests used reject the null hypothesis of cross-sectional independence. This result recommends the use of the second-generation panel unit root tests for all series. 
The software Stata v. 15 in order to apply the Pesaran's CIPS test was used. The results are provided in Table 5.

Tab. 5 - The overview of the Pesaran's CIPS test statistic for unit roots in heterogeneous panels. Source: own research

\begin{tabular}{|l|c|c|}
\hline \multicolumn{1}{|c|}{ Variable } & Without trend & With trend \\
\hline GDP & -1.55 & -1.98 \\
\hline FDI & -3.28 & -3.40 \\
\hline FDIP & -4.35 & -4.29 \\
\hline rGDP & -2.85 & -3.02 \\
\hline rFDI & -3.55 & -3.92 \\
\hline rFDIP & -3.64 & -3.70 \\
\hline LogGDP & -2.39 & -2.13 \\
\hline LogFDI & -3.89 & -4.47 \\
\hline LogFDIP & -4.36 & -4.18 \\
\hline$\Delta$ GDP & -2.86 & -3.10 \\
\hline$\Delta$ FDI & -4.88 & -4.75 \\
\hline$\Delta$ FDIP & -5.37 & -5.45 \\
\hline$\Delta$ rGDP & -4.22 & -3.85 \\
\hline$\Delta$ rFDI & -5.79 & -5.70 \\
\hline$\Delta$ rFDIP & -5.76 & -5.68 \\
\hline$\Delta$ LogGDP & -2.82 & -2.98 \\
\hline$\Delta$ LogFDI & -5.48 & -5.21 \\
\hline$\Delta$ LogFDIP & -5.35 & -5.36 \\
\hline
\end{tabular}

Note: individual dynamics specifications in each regression is based on the Wald test of composite linear hypothesis about the parameters of the model. The $10 \%, 5 \%$ and $1 \%$ critical values for the model without trend are $-2.14,-2.26$ and -2.47 , and $-2.67,-2.78$ and -3.01 for the model with trend, respectively.

For all series, with the exception of only two series, it is indicated by the Pesaran CIPS test that the null hypothesis of unit root should be rejected at $\mathrm{p}<.01$ in all panels. The GDP and LogGDP (model with trend) are two exceptions, where Pesaran CIPS test indicated unit root in all panels.

As shown in Table 3, the null hypothesis of common unit root for all series at all significance levels is rejected by tests of Levin et al. (2002) and Breitung (2000, 2002). There was an identical conclusion while the Im et al. (2003), ADF Fisher and PP Fisher tests were being used. However, there were two exceptions. The tests for series GDP and LogGDP suggested that the null hypothesis of unit root with individual trend cannot be rejected. However, all series null hypothesis of stationarity are rejected by the Hadri (2000) test and the test based on heteroscedastic consistent Z-statistic, which is contrary to the results of the above tests. Such mixed results can potentially occur if these tests have a lower power in case of the structural break in time series, which is transparent in case of GDP and LogGDP series. 
Accordingly, some of the series have strong cross-sectional dependence. The higher reliability of the results of first-generation panel unit root tests was shown by the Pesaran CPIS tests. Finally, it can be said that all series are $\mathrm{I}(0)$ both in level and the first difference, with GDP and LogGDP being the only exception and considered as I(1).

\subsection{Panel cointegration tests (ARDL model)}

Unit root tests result suggested that GDP/LogGDP and FDI/LogFDI series are in different order of integration. Therefore, the procedure of Johansen (1991) to test cointegration is recommended. Cointegration tests based on the ARDL model will be used for these series.

For the purpose of investigating the long-term and short-term cointegration correlations between GDP and FDI and extracting the error correction version of the panel characteristics to identify the short-term dynamic, the panel ARDL technique was selected. The preferred panel method was ARDL method then traditional cointegration techniques, e.g. Johansen (1991) cointegration test, for it could be used with the studied factors no matter if they were $\mathrm{I}(0), \mathrm{I}(1)$, or both $\mathrm{I}(0)$ and $\mathrm{I}(1)$. Both coefficients are provided at once using the panel ARDL.

The following attitude is founded on the usage of the panel form of ARDL model suggested by Pesaran \& Shin (1999) and Pesaran et al. (2001). To access the impact of the optimal lag length criteria on the ARDL results, the information criterion (AIC, Akaike, 1974) and information criterion (SIC, Schwarz, 1978) were used. The ARDL models for both original and logarithm transformation of the original series have also been estimated. Lastly, the ARDL models were estimated with two different trend specifications, being constant level and linear trend.

For at least two reasons, the preferred models are ARDL models based on logarithm transformation of the original series. First of all, the literature of ARDL models is mostly based on logarithm transformed series. Secondly, in such models, the interpretation of the coefficients is shown to be more intuitive. Coefficients in these models are elasticities, which shows for how much the dependent variable for $1 \%$ change in independent variables will change. Hence, all the results are being presented, but only those models with logarithm transformed series only will be commented on.

Tab. 6 - The estimation of ARDL (PMG) panel (dependent variable being: GDP). Source: own research

\begin{tabular}{|l|l|l|l|l|l|l|}
\hline \multirow{2}{*}{ Variable } & \multicolumn{7}{l}{ Constant } & \multicolumn{2}{l|}{ Linear trend } \\
\cline { 2 - 8 } & Coefficient & t-statistic & P-value & Coefficient & t-statistic & P-value \\
\hline & \multicolumn{7}{|l|}{ Long run equation } \\
\hline FDI & 827.83 & 0.14 & .89 & 1.7689 & 8.46 & $<.01$ \\
\hline $\begin{array}{l}\text { Cointegration } \\
\text { equation }\end{array}$ & -0.0008 & -2.69 & $<.01$ & -0.3016 & -4.38 & $<.01$ \\
\hline$\Delta$ GDP(-1) & & & & 0.4203 & 7.28 & $<.01$ \\
\hline$\Delta$ FDI & 0.7421 & 2.24 & .03 & 0.6065 & 1.78 & .08 \\
\hline
\end{tabular}




\begin{tabular}{|l|l|l|l|l|l|l|}
\hline Trend & & & & $1.59 \mathrm{E}+9$ & 2.22 & .03 \\
\hline Constant & $2.73 \mathrm{E}+9$ & 2.72 & $<.01$ & $2.90 \mathrm{E}+9$ & 0.61 & .54 \\
\hline
\end{tabular}

Note: SIC was used for an optimal lag length selection. ARDL $(1,1)$ model with constant and ARDL $(2,1)$ model with trend were selected.

Tab. 7 - The estimation of ARDL (PMG) panel (dependent variable being: GDP). Source: own research

\begin{tabular}{|c|c|c|c|c|c|c|}
\hline \multirow{2}{*}{ Variable } & \multicolumn{3}{|l|}{ Constant } & \multicolumn{3}{|l|}{ Linear trend } \\
\hline & Coefficient & t-statistic & P-value & Coefficient & t-statistic & P-value \\
\hline & \multicolumn{6}{|c|}{ Long run equation } \\
\hline \multirow[t]{2}{*}{ FDI } & 39.0379 & 5.05 & $<.01$ & 1.5819 & 10.84 & $<.01$ \\
\hline & \multicolumn{6}{|c|}{ Short run equation } \\
\hline $\begin{array}{l}\text { Cointegration } \\
\text { equation }\end{array}$ & 0.0098 & 0.63 & .53 & -0.2795 & -2.72 & $<.01$ \\
\hline$\Delta \mathrm{GDP}(-1)$ & 0.2211 & 2.53 & .01 & 0.3286 & 4.02 & $<.01$ \\
\hline$\Delta \mathrm{GDP}(-2)$ & -0.0802 & -0.92 & .36 & & & \\
\hline$\Delta \mathrm{FDI}$ & 1.6063 & 2.39 & .02 & 0.7713 & 1.79 & .08 \\
\hline$\Delta \mathrm{FDI}(-1)$ & 1.1548 & 2.39 & .02 & 0.6322 & 1.93 & .06 \\
\hline$\Delta \mathrm{FDI}(-2)$ & 0.5432 & 2.03 & .04 & 0.1805 & 0.72 & .47 \\
\hline$\Delta \mathrm{FDI}(-3)$ & 0.5273 & 3.40 & $<.01$ & 0.4028 & 3.05 & $<.01$ \\
\hline Trend & & & & $9.43 \mathrm{E} 8$ & 2.37 & .02 \\
\hline Constant & $3.14 \mathrm{E}+9$ & 2.96 & $<.01$ & $9.63 \mathrm{E}+7$ & 0.02 & .99 \\
\hline
\end{tabular}

Note: AIC was used for an optimal lag length selection. ARDL $(3,4)$ model with constant and ARDL $(2,4)$ model with trend were selected.

Tab. 8 - The estimation of ARDL (PMG) panel (dependent variable being: GDP). Source: own research

\begin{tabular}{|c|c|c|c|c|c|c|}
\hline \multirow{2}{*}{ Variable } & \multicolumn{3}{|l|}{ Constant } & \multicolumn{3}{|l|}{ Linear trend } \\
\hline & Coefficient & t-statistic & $\mathrm{P}$-value & Coefficient & t-statistic & P-value \\
\hline & \multicolumn{6}{|c|}{ Long run equation } \\
\hline \multirow[t]{2}{*}{ FDIP } & $7.08 \mathrm{E}+9$ & 1.75 & .08 & $2.50 \mathrm{E}+9$ & 7.67 & $<.01$ \\
\hline & \multicolumn{6}{|c|}{ Short run equation } \\
\hline $\begin{array}{l}\text { Cointegration } \\
\text { equation }\end{array}$ & -0.0290 & -2.55 & .01 & -0.2485 & -3.96 & $<.01$ \\
\hline$\Delta$ FDIP & $4.19 \mathrm{E}+8$ & 1.56 & .12 & $-8.89 \mathrm{E}+7$ & -0.51 & .61 \\
\hline Trend & & & & $1.85 \mathrm{E}+9$ & 1.78 & .08 \\
\hline Constant & $5.85 \mathrm{E}+9$ & 3.94 & $<.01$ & $-4.18 \mathrm{E}+9$ & -0.89 & .93 \\
\hline
\end{tabular}

Note: SSIC was used for an optimal lag length selection. ARDL $(1,1)$ model was selected. 
Tab. 9 - The estimation of ARDL (PMG) panel (dependent variable being: GDP). Source: own research

\begin{tabular}{|c|c|c|c|c|c|c|}
\hline \multirow{2}{*}{ Variable } & \multicolumn{3}{|l|}{ Constant } & \multicolumn{3}{|c|}{ Linear trend } \\
\hline & Coefficient & t-statistic & P-value & Coefficient & t-statistic & P-value \\
\hline & \multicolumn{6}{|c|}{ Long run equation } \\
\hline \multirow[t]{2}{*}{ FDIP } & $1.28 \mathrm{E}+11$ & 0.20 & .84 & $7.34 \mathrm{E}+8$ & 8.08 & $<.01$ \\
\hline & \multicolumn{6}{|c|}{ Short run equation } \\
\hline $\begin{array}{l}\text { Cointegration } \\
\text { equation }\end{array}$ & -0.0008 & -0.78 & .44 & -0.2972 & -4.89 & $<.01$ \\
\hline$\Delta \mathrm{GDP}(-1)$ & 0.3477 & 4.84 & $<.01$ & 0.4402 & 7.94 & $<.01$ \\
\hline$\triangle \mathrm{FDIP}$ & 7.93E8 & 2.02 & .05 & $3.73 \mathrm{E}+8$ & 1.41 & .16 \\
\hline$\Delta \mathrm{FDIP}(-1)$ & $4.32 \mathrm{E} 8$ & 2.70 & $<.01$ & & & \\
\hline Trend & & & & $1.87 \mathrm{E}+9$ & 2.07 & .04 \\
\hline Constant & 3.37E9 & 3.50 & $<.01$ & $4.92 \mathrm{E}+8$ & 0.11 & .91 \\
\hline
\end{tabular}

Note: AIC was used for an optimal lag length selection. ARDL $(2,2)$ model with constant and ARDL $(2,1)$ model with trend were selected.

Tab. 10 - The estimation of ARDL (PMG) panel (dependent variable being: LogGDP). Source: own research

\begin{tabular}{|c|c|c|c|c|c|c|}
\hline \multirow{2}{*}{ Variable } & \multicolumn{3}{|l|}{ Constant } & \multicolumn{3}{|l|}{ Linear trend } \\
\hline & Coefficient & t-statistic & P-value & Coefficient & t-statistic & P-value \\
\hline & \multicolumn{6}{|c|}{ Long run equation } \\
\hline \multirow[t]{2}{*}{ LogFDI } & 0.3019 & 4.88 & $<.01$ & 0.0854 & 12.18 & $<.01$ \\
\hline & \multicolumn{6}{|c|}{ Short run equation } \\
\hline $\begin{array}{l}\text { Cointegration } \\
\text { equation }\end{array}$ & -0.0396 & -2.43 & .02 & -0.2056 & -3.14 & $<.01$ \\
\hline$\Delta \operatorname{LogFDI}$ & 0.0046 & 1.07 & .28 & -0.0047 & -3.17 & $<.01$ \\
\hline Trend & & & & 0.0045 & 2.38 & .02 \\
\hline Constant & 0.6180 & 2.59 & .01 & 4.8207 & 3.17 & $<.01$ \\
\hline
\end{tabular}

Note: SSIC was used for an optimal lag length selection. ARDL $(1,1)$ model was selected.

Tab. 11 - The estimation of ARDL (PMG) panel (dependent variable: LogGDP). Source: own research

\begin{tabular}{|l|l|l|l|l|l|l|}
\hline \multirow{2}{*}{ Variable } & \multicolumn{7}{|l|}{ Constant } & Linear trend \\
\cline { 2 - 7 } & Coefficient & t-statistic & P-value & Coefficient & t-statistic & P-value \\
\hline & \multicolumn{7}{|c|}{ Long run equation } \\
\hline LogFDI & 0.2912 & 4.54 & $<.01$ & 0.0828 & 13.59 & $<.01$ \\
\hline & -0.0223 & -1.60 & .11 & -0.2042 & -3.01 & $<.01$ \\
\hline $\begin{array}{l}\text { Cointegration } \\
\text { equation }\end{array}$ & & & & & & \\
\hline
\end{tabular}




\begin{tabular}{|l|l|l|l|l|l|l|}
\hline$\Delta \log G D P(-1)$ & 0.3564 & 5.97 & $<.01$ & 0.2711 & 3.62 & $<.01$ \\
\hline$\Delta \operatorname{LogFDI}$ & 0.0057 & 1.26 & .21 & -0.0040 & -1.99 & .05 \\
\hline Trend & & & & 0.0048 & 2.48 & .01 \\
\hline Constant & 0.4539 & 1.69 & .09 & 4.7804 & 3.03 & $<.01$ \\
\hline
\end{tabular}

Note: AIC was used for an optimal lag length selection. The model ARDL $(2,1)$ was selected.

Tab. 12 - The estimation of ARDL (PMG) panel (dependent variable: LogGDP). Source: own research

\begin{tabular}{|c|c|c|c|c|c|c|}
\hline \multirow{2}{*}{ Variable } & \multicolumn{3}{|l|}{ Constant } & \multicolumn{3}{|l|}{ Linear trend } \\
\hline & Coefficient & t-statistic & P-value & Coefficient & t-statistic & P-value \\
\hline & \multicolumn{6}{|c|}{ Long run equation } \\
\hline \multirow[t]{2}{*}{ LogFDIP } & 0.7996 & 2.63 & $<.01$ & 0.1983 & 8.50 & $<.01$ \\
\hline & \multicolumn{6}{|c|}{ Short run equation } \\
\hline $\begin{array}{l}\text { Cointegration } \\
\text { equation }\end{array}$ & -0.0327 & -3.71 & $<.01$ & -0.2067 & -4.46 & $<.01$ \\
\hline$\Delta \operatorname{LogFDIP}$ & 0.0045 & 0.97 & .33 & -0.0100 & -2.86 & $<.01$ \\
\hline Trend & & & & 0.0058 & 4.08 & $<.01$ \\
\hline Constant & 0.8185 & 3.93 & $<.01$ & 5.04 & 4.51 & $<.01$ \\
\hline
\end{tabular}

Note: SIC was used for an optimal lag length selection. The model ARDL $(2,1)$ was selected.

Tab. 13 - The estimation of ARDL (PMG) panel (dependent variable: LogGDP). Source: own research

\begin{tabular}{|c|c|c|c|c|c|c|}
\hline \multirow{2}{*}{ Variable } & \multicolumn{3}{|l|}{ Constant } & \multicolumn{3}{|l|}{ Linear trend } \\
\hline & Coefficient & t-statistic & P-value & Coefficient & t-statistic & P-value \\
\hline & \multicolumn{6}{|c|}{ Long run equation } \\
\hline \multirow[t]{2}{*}{ LogFDIP } & 3.798 & 0.56 & .57 & 0.1286 & 9.32 & $<.01$ \\
\hline & \multicolumn{6}{|c|}{ Short run equation } \\
\hline $\begin{array}{l}\text { Cointegration } \\
\text { equation }\end{array}$ & -0.0036 & -1.99 & .05 & -0.2353 & -4.73 & $<.01$ \\
\hline$\Delta \log G D P(-1)$ & 0.3468 & 4.79 & $<.01$ & 0.2870 & 3.98 & $<.01$ \\
\hline$\Delta \operatorname{LogFDIP}$ & 0.0141 & 1.96 & .05 & -0.0026 & -0.63 & .53 \\
\hline Trend & & & & 0.0072 & 4.29 & $<.01$ \\
\hline Constant & 0.0959 & 2.46 & .02 & 5.7331 & 4.76 & $<.01$ \\
\hline
\end{tabular}

Note: AIC was used for an optimal lag length selection. The model ARDL $(2,1)$ was selected.

The coefficient of the error correction term (ECT) is lined up with the underlying convergence assumptions in validation of the long-run equilibrium nature of the model. These assumptions include that the ECT is negative, significant, and less than one (Pesaran et al., 1999). Comments follow on the results of models based on the Schwarz information criterion presented in Tables 10 and 12. The Schwarz information criterion has a tendency to underestimate optimal 
lag length, which could leave some residual autocorrelation. The Akaike information criterion has a tendency to overestimate the optimal lag length, but this has a less serious influence on the reliability of the estimated panel ARDL model. Regardless, in this specific panel data, the suggested ARDL models are in reality not that very different: ARDL (1,1) with Schwarz criterion and ARDL $(2,1)$ with Akaike criterion. With this exception, the coefficients in the model based on the Schwarz criterion are statistically more significant.

The cointegrating equations (a model with constant: -0.0396 and a model with trend: -0.2056 ) in Table 10 provide explanation of the rate of adjustment back to (long-run) equilibrium being $3.96 \%$ (model with constant) and 20.56\% (model with trend) which are significant at less than $\mathrm{p}<$.01. In short term, significantly related to LogGDP, at less than $\mathrm{p}<.01$ in the model with trend, is only the coefficient of LogFDI.

Comparable results are presented for the LogFDIP series in Table 12. In this particular case, the cointegrating equations (a model with constant: -0.0327 and a model with trend: -0.2067 ) explain that the rate of adjustment back to (long-run) equilibrium is $3.27 \%$ (model with constant) and $20.67 \%$ (model with trend) which are significant at $\mathrm{p}<.01$. However, short-lived, only the coefficient of LogFDIP is significantly related to LogGDP, at less than $\mathrm{p}<.01$, but only in the model with this trend.

The panel ARDL is a long-run estimate of the analysis of equilibrium. Consequently, a higher importance to the long-run coefficients is given. All long-run coefficients are positive and statistically significant. For example, the long-run coefficients for LogFDI (0.3019) in the model with the constant and in the model with the trend (0.0854) in Table 10 are statistically significant at $\mathrm{p}$ $<$.01. In Table 12, the long-run coefficients for LogFDIP in the models with the constant and trend 0.7996 and 0.1983 respectively. These coefficients indicate that a $1 \%$ increase in LogFDIP (logarithm of FDI to GDP) increases LogGDP between $0.1983 \%$ and $0.7996 \%$.

Thus, there is a long-run relationship between LogGDP, LogFDI and LogFDIP series in the case of the EU13 countries for the period under investigation (2002-2018), which was confirmed by a cointegration test based on the panel ARDL (PMG) model.

\subsection{Granger causality analysis}

The simple definition of Granger causality in the case of the two series is as follows. Series X is said to cause in Granger a series $\mathrm{Y}$, if $\mathrm{Y}$ can be better predicted by using past values of series $\mathrm{X}$ and $\mathrm{Y}$ than just using past values of series $\mathrm{Y}$. The theoretical result suggests that if the series are cointegrated, a causal relationship emerges between them in Granger, but not the other way around. If there is a causal link in Granger between series, this does not mean that the series are cointegrated. Finally, even if the series are not cointegrated, it is possible to examine the existence of a causal relationship between them.

Using the panel Granger non-causality test developed by Dumitrescu \& Hurlin (2012), testing was performed to determine whether there is a causal relationship among the variables The null hypothesis is the following: variable $\mathrm{X}$ does not homogeneously cause variable $\mathrm{Y}$, against the alternative hypothesis that $\mathrm{X}$ does Granger-cause $\mathrm{Y}$ for at least one panel. The following table presents the results of this test. 
Tab. 14 - The causality test of Dumitrescu-Hurlin panel. Source: own research

\begin{tabular}{|c|c|c|c|c|}
\hline $\begin{array}{l}\text { Null hypothesis } \\
\text { v1 does not Granger-cause v2 }\end{array}$ & $\overline{\mathrm{W}}$ & $\overline{\mathrm{Z}}$ & $\widetilde{Z}$ & Causality* \\
\hline rGDP (v1) FDI (v2) & 1.62 & $1.57(.25)$ & $0.69(.47)$ & No \\
\hline FDIP (v1) rGDP (v2) & 1.48 & $1.23(.44)$ & $0.46(.75)$ & No \\
\hline rGDP (v1) FDIP (v2) & 1.12 & $0.30(.80)$ & $-0.18(.82)$ & No \\
\hline LogFDI (v1) $\Delta \log G D P(v 2)$ & 1.33 & $0.84(.58)$ & $0.23(.89)$ & No \\
\hline$\Delta \operatorname{LogGDP}(\mathrm{v} 1) \operatorname{LogFDI}(\mathrm{v} 2)$ & 2.43 & $3.65(.15)$ & $2.23(.15)$ & No \\
\hline LogFDIP (v1) $\Delta \operatorname{LogGDP}(v 2)$ & 1.64 & $1.62(.29)$ & $0.79(.46)$ & No \\
\hline$\Delta \log G D P(v 1) \operatorname{LogFDIP}(v 2)$ & 1.96 & $2.44(.26)$ & $1.37(.32)$ & No \\
\hline LogFDI v(1) LogGDP (v2) & 0.52 & $-1.22(.35)$ & $-1.23(.24)$ & No \\
\hline LogGDP (v1) LogFDI (v2) & 1.34 & $0.87(.63)$ & $0.30(.88)$ & No \\
\hline LogFDIP (v1)LogGDP (v2) & 2.57 & $1.02(.70)$ & $0.07(.97)$ & No \\
\hline LogGDP (v1) LogFDIP (v2) & 2.00 & $2.54(.25)$ & $1.52(.25)$ & No \\
\hline$\Delta \operatorname{LogFDI}(\mathrm{v} 1) \Delta \log G \mathrm{DP}(\mathrm{v} 2)$ & 0.55 & $-1.16(.46)$ & $-1.19(.31)$ & No \\
\hline$\Delta \log G D P(v 1) \Delta \operatorname{LogFDI}(v 2)$ & 9.40 & $13.34(.01)$ & $7.14(.01)$ & Yes \\
\hline$\Delta \operatorname{LogFDIP}(\mathrm{v} 1) \Delta \log G D P(\mathrm{v} 2)$ & 0.78 & $-0.55(.72)$ & $-0.75(.52)$ & No \\
\hline$\Delta \operatorname{LogGDP}(\mathrm{v} 1) \Delta \operatorname{LogFDIP}(\mathrm{v} 2)$ & 3.72 & $3.10(.14)$ & $1.20(.29)$ & No \\
\hline
\end{tabular}

Note: P-values were computed using 100 bootstrap replications and provided in the brackets. BIC criterion used to decide on the optimal number of lags. * The decisions were made based on the $5 \%$ significance level.

As shown in the table above, the causal relationship between any two variables dos not exist with only one exception. There is a causal relationship between the GDP growth rate ( $\triangle$ LogGDP) and the FDI growth rate ( $\Delta \operatorname{LogFDI})$. It can be concluded that the GDP growth rate causes the FDI growth rate of at least $\mathrm{p}<.01$, while the FDI growth rate does not cause the GDP growth rate. Respectfully, the relationship between the GDP growth rate and FDI growth rate has been shown indirectly.

The expected result is that, if there is a cointegration between two series, in that case they are also causally related. Despite that, this is not confirmed by the mixed results of a cointegration test based on the ARDL (PMG) model and the Dumitrescu-Hurlin panel causality test. This can result from the lower power of these tests and a weak relationship between series. In that sense, it can be claimed that there is no significantly shown positive impact of FDI on GDP growth in the most recent European Union member countries. 
Finally, the results of the present paper are aligned with the results obtained by Iacovoiu (2018) who found a weak positive the relationship between the level of economic development and FDI. Kurecic et al. (2015) determined a relation between these variables in Central and Eastern European countries, albeit with difficulty to prove causality. On the other hand, Vojtovic et al. (2019) found FDI has an impact on economic growth using a sample of Central and Eastern European countries. Unidirectional causality between FDI and the GDP growth was also found by Carp (2015) with a sample of countries from Central and Eastern Europe. However, Stanisic (2008) did not find a positive correlation between FDI and GDP using a sample of countries of Southeast Europe. It is clear that the results of similar studies are rather heterogeneous.

\section{CONCLUSION}

Paper attempts to investigate the relationship between FDI and GDP in the EU13 countries. Based on our analysis using annual time series for EU13 countries in the period from 2002 to 2018, we can conclude that there is only weak evidence that FDI had a statistically significant impact on the GDP. Namely, these conclusion comes as a result of different cointegration tests, as well as causality tests, which were employed in the paper. We found evidence of the a longrun equilibrium between the $\log$ GDP, LogFDI and LogFDIP series. Interestingly, results have shown that $1 \%$ increase in LogFDI increases LogGDP between $0.0828 \%$ and $0.3019 \%$. Finally, only indirect relationship between the GDP growth rate and FDI growth rate is indicated by panel causality test.

Although, it is commonly believed that higher levels of FDI inflow influence positively GDP growth, and vice versa too, these results, however, do concur with the common belief that FDI has a positive effect on economic growth.

Limitations of our research and recommendations for future researches can be divided into two groups: (1) number of variables included and (2) number of countries included. These groups of limitations are interconnected.

The limitations of our research can be seen primarily in not including other variables which could have an impact on FDI and GDP. Future research should take into consideration other factors that might influence FDI and economic growth, e.g. institutional quality, human capital, market size, openness, etc. Type and the size of the government invectives for FDI also are considered to play an important role in attracting FDI (tax deductions, etc.).

Also, from the results of the conducted analysis, the necessity for single-country studies is also made clear due to possibly heterogeneous relationships between FDI and growth. In these studies, country-specific factors and environment can be taken into account, besides all mentioned, financial development, the participation of the private sector in investment and economic growth, incentives for FDI, prices, innovation capacity, etc. Great role in magnitude of the FDI inflow impact on the GDP has the level of the absorption capacity of the recipient country, i.e. the ability of the country to obtain spill over effects.

Increasing of the number of observations to elicit comparisons and contrasts between individual countries as well as among groupings of national and regional economies is also imperative. 


\section{References}

1. Akaike, H. (1974). A new look at the statistical model identification. IEEE Transactions on Automatic Control, 19 (6), 716-723. https://doi.org/10.1109/tac.1974.1100705

2. Ausloos, M., Eskandary, A., Kaur, P., \& Dhesi, G. (2019). Evidence for Gross Domestic Product growth time delay dependence over Foreign Direct Investment. A time-lag dependent correlation study. Physica A: Statistical Mechanics and Its Applications, 527, 121181, 1-22 https:// doi.org/10.1016/j.physa.2019.121181

3. Breitung, J. (2000). The Local Power of Some Unit Root Tests for Panel Data, in B. Baltagi (ed.), Advances in Econometrics, Vol. 15: Nonstationary Panels, Panel Cointegration, and Dynamic Panels, Amsterdam: JAI Press, 161-178. https://doi.org/10.1016/s07319053(00)15006-6

4. Breitung, J. (2002). Nonparametric tests for unit roots and cointegration. Journal of Econometrics, 108 (2), 343-363. https://doi.org/10.1016/s0304-4076(01)00139-7

5. Carp, L. (2015). FDI and Economic Growth in CEE Countries. SEA-Practical Application of Science, 3 (7), 21-26.

6. Cicak, K. \& Soric, P. (2015). The Interrelationship of FDI and GDP in European Transition Countries. International Journal of Management Science and Business Administration, 1 (4), 41-58. https://doi.org/10.18775/ijmsba.1849-5664-5419.2014.14.1003

7. Dickey, D. A. \& Fuller, W. A. (1981). Likelihood ratio statistics for autoregressive time series with a unit root. Econometrica, 49 (4), 1057-1072. https://doi.org/10.2307/1912517

8. Dickey, D. A. \& Fuller W. A. (1979). Distribution of the Estimators for Autoregressive Time Series with a Unit Root. Journal of the American Statistical Association, 74 (366), 427-431. https:// doi.org/10.2307/2286348

9. Dumitrescu, E. I., \& Hurlin, C. (2012). Testing for Granger non-causality in heterogeneous panels. Economic Modelling, 29 (4), 1450-1460. https://doi.org/10.1016/j.econmod.2012.02.014

10. Hadri, K. (2000). Testing for Stationarity in Heterogeneous Panel Data. Econometric Journal, 3 (2), 148-161. https://doi.org/10.1111/1368-423x.00043

11. Iacovoiu, V. B. (2018). The Relationship between Economic Development and Foreign Direct Investment Flows. Economic Insights - Trends and Challenges, 70 (3), 13-20.

12. Iamsiraroj, S. \& Ulubaşoğlu, M. A. (2015). Foreign direct investment and economic growth: A real relationship or wishful thinking? Economic Modelling, 51, 200-213. https://doi. org/10.1016/j.econmod.2015.08.009

13. Im, K. S., Pesaran, M. H. \& Shin, Y. (2003). Testing for Unit Roots in Heterogeneous Panels. Journal of Econometrics, 115 (1), 53-74. https://doi.org/10.1016/s0304-4076(03)00092-7

14. Johansen, S. (1991). Estimation and Hypothesis Testing of Cointegration Vectors in Gaussian Vector Autoregressive Models. Econometrica, 59 (6), 1551-1580. https://doi. $\operatorname{org} / 10.2307 / 2938278$

15. Kurecic, P., Luburic, G. \& Simovic, V. (2015). The Interdependence of GDP per capita and Foreign Direct Investment in the Transitional Economies of Central and Eastern Europe. Journal of economic and social development, 2 (2), 77-84. 
16. Lasbrey, A., Enyoghasim, M., Tobechi, A., Uwajumogu, N., Chukwu, B., \& Kennedy, O. (2018) Foreign Direct Investment and Economic Growth: Literature from 1980 to 2018. International Journal of Economics and Financial Issues, 8 (5), 309-318.

17. Levin, A., Lin C. F., \& Chu C. (2002). Unit Root Tests in Panel Data: Asymptotic and Finite-Sample Properties. Journal of Econometrics, 108 (1), 1-24. https://doi.org/10.1016/s03044076(01)00098-7

18. Lopez, L., \& Weber, S. (2017). XTGCAUSE: Stata module to test for Granger non-causality in heterogeneous panels. Statistical Software Components S458308, Boston College Department of Economics.

19. Markusen, J. R., \& Venables, A. J. (1997). Foreign direct investment as a catalyst for industrial development. National Bureau of Economic Research, Working Paper No. 6241.

20. Meyer, K. (2015). What is "strategic asset seeking FDI"? Multinational Business Review, 23 (1), 57-66. https://doi.org/10.1108/MBR-02-2015-0007

21. Moudatsou, A. (2003). Foreign Direct Investment and Economic Growth in the European Union. Journal of Economic Integration, 18 (4), 689-707. https://doi.org/10.11130/jei.2003.18.4.689

22. Pesaran, M. H. (2007). A simple panel unit root test in the presence of cross-section dependence. Journal of Applied Econometrics, 22 (2), 265-312. https://doi.org/10.1002/jae.951

23. Pesaran, M. H. \& Shin, Y. (1999). An Autoregressive Distributed-Lag Modelling Approach to Cointegration Analysis, in Strøm, S. (ed.) Econometrics and Economic Theory in the 20th Century: The Ragnar Frisch Centennial Symposium. Cambridge: Cambridge University Press (Econometric Society Monographs), 371-413. https://doi.org/10.1017/CCOL521633230.011.

24. Pesaran, M. H., Shin, Y. \& Smith, R. J. (2001). Bounds testing approaches to the analysis of level relationships. Journal of Applied Econometrics, 16 (3), 289-326. https://doi.org/10.1002/ jae.616

25. Popescu, G. H. (2014). FDI and Economic Growth in Central and Eastern Europe. Sustainability, 6 (11), 8149-8163. https://doi.org/10.3390/su6118149

26. Schwarz, G. E. (1978). Estimating the dimension of a model. The Annals of Statistics, 6 (2), 461-464. https://doi.org/10.1214/aos/1176344136

27. Sothan, S. (2017). strong evidence on the causal impact of FDI on Cambodia's economic growth (GDP). Economics \& Finance, 5 (1), 1277860. https://doi.org/10.1080/23322039.2016.12 77860

28. Stanisic, N. (2008). Do Foreign Direct Investments Increase the Economic Growth of Southeastern European Transition Economies? South-Eastern Europe Journal of Economics, 1, $29-38$.

29. Su, W., Zhang, D., Zhang, C., Abrhám, J., Simonescu, M., Yaroshevich, N., \& Guseva, V. (2018). Determinants of Foreign Direct Investment in the Visegrad Group Countries after the EU Enlargement. Technological and Economic Development of Economy, 24 (5), 1955-1978. https:// doi.org/10.3846/tede.2018.5487

30. Vojtovic, S., Klimaviciene, A., \& Pilinkiene, V. (2019) The Linkages between Economic Growth and FDI in CEE Countries. Ekonomický ćasopis, 67 (3), 264-279. 


\section{Contact information}

prof. Vlatka Bilas, Ph.D.

University of Zagreb

Faculty of Economics and Business

Department of International Economics

Croatia

E-mail: bilas.vlatka@gmail.com

ORCID:0000-0002-9021-6651 